\title{
On the Hardness and Elastic Modulus of Phases in SiC-Reinforced Al Composite: Role of La and Ce Addition
}

\author{
Andong Du ${ }^{1,2}$, Lucia Lattanzi ${ }^{3}{ }^{\mathbb{D}}$, Anders Wollmar Eric Jarfors ${ }^{1,3} * \mathbb{D}$, Jinchuan Zheng ${ }^{1}$, Kaikun Wang ${ }^{2, *}$ \\ and Gegang Yu ${ }^{1}$
}

check for updates

Citation: Du, A.; Lattanzi, L.; Jarfors, A.W.E.; Zheng, J.; Wang, K.; Yu, G. On the Hardness and Elastic Modulus of Phases in SiC-Reinforced Al Composite: Role of $\mathrm{La}$ and Ce Addition. Materials 2021, 14, 6287 . https://doi.org/10.3390/ma14216287

Academic Editor: Dina Dudina

Received: 20 August 2021

Accepted: 13 October 2021

Published: 21 October 2021

Publisher's Note: MDPI stays neutral with regard to jurisdictional claims in published maps and institutional affiliations.

Copyright: (c) 2021 by the authors. Licensee MDPI, Basel, Switzerland. This article is an open access article distributed under the terms and conditions of the Creative Commons Attribution (CC BY) license (https:/ / creativecommons.org/licenses/by/ $4.0 /)$.
1 Institute of Semi-Solid Metal Technology, China Academy of Machinery Sciences and Technology (Jiangle), No. 22 Huancheng East Road, Jiangle, Sanming 353300, China; b20170186@xs.ustb.edu.cn (A.D.); zhengjc@cam.com.cn (J.Z.); yugg@cam.com.cn (G.Y.)

2 Department of Materials Processing and Control Engineering, School of Materials Science and Engineering, University of Science and Technology Beijing, Xueyuan Road No. 30, Beijing 100083, China

3 Department of Materials and Manufacturing, School of Engineering, Jönköping University, 55111 Jönköping, Sweden; lucia.lattanzi@ju.se

* Correspondence: anders.jarfors@ju.se (A.W.E.J.); kkwang@mater.ustb.edu.cn (K.W.)

\begin{abstract}
The use of silicon carbide particles ( $\mathrm{SiCp}$ ) as reinforcement in aluminium (Al)-based composites $(\mathrm{Al} / \mathrm{SiCp})$ can offer high hardness and high stiffness. The rare-earth elements like lanthanum (La) and cerium $(\mathrm{Ce})$ and transition metals like nickel $(\mathrm{Ni})$ and copper $(\mathrm{Cu})$ were added into the matrix to form intermetallic phases; this is one way to improve the mechanical property of the composite at elevated temperatures. The $\alpha-\mathrm{Al}_{15}(\mathrm{Fe}, \mathrm{Mn})_{3} \mathrm{Si}_{2}, \mathrm{Al}_{20}(\mathrm{La}, \mathrm{Ce}) \mathrm{Ti}_{2}$, and $\mathrm{Al}_{11}(\mathrm{La}, \mathrm{Ce})_{3}$, $\pi-\mathrm{Al}_{8} \mathrm{FeMg}_{3} \mathrm{Si}_{6}$ phases are formed. Nanoindentation was employed to measure the hardness and elastic modulus of the phases formed in the composite alloys. The rule of mixture was used to predict the modulus of the matrix alloys. The Halpin-Tsai model was applied to calculate the elastic modulus of the particle-reinforced composites. The transition metals ( $\mathrm{Ni}$ and $\mathrm{Cu}$ ) and rare-earth elements (La and $\mathrm{Ce}$ ) determined a $5-15 \%$ increase of the elastic modulus of the matrix alloy. The SiC particles increased the elastic modulus of the matrix alloy by $10-15 \%$ in composite materials.
\end{abstract}

Keywords: metal matrix composites; aluminium alloys; SiCp; nanoindentation; lanthanum; cerium; hardness; elastic modulus; transition metals; rare-earth elements

\section{Introduction}

The aluminium-silicon alloys (Al-Si) reinforced with oxides and carbide, commonly referred to as $\mathrm{Al}$ metal matrix composites (Al-MMCs), were initially investigated in the 1990s [1-4]. Interest in these materials has significantly increased in recent years [5-7]. The main reason behind this is the increasing demand for lightweight components, as these are the critical routes to reduce $\mathrm{CO}_{2}$ emission and fuel consumption [8,9]. These composites are also suitable for upcoming vehicle electrification that determines additional requirements in vehicle safety and particulate emission, especially dust from braking systems operating at $400{ }^{\circ} \mathrm{C}$ [6]. Using silicon carbide particles (SiCp) as reinforcement in $\mathrm{Al} / \mathrm{SiCp}$ composites can offer high hardness and stiffness. The high hardness would promote excellent wear resistance making $\mathrm{Al} / \mathrm{SiCp}$ composites highly suited for brake discs, and the increased stiffness compared to Al-Si alloys could offer a route to further weight reduction [5].

The drawback of Al-based composites lies in the high-temperature performance since the Al matrix suffers from softening during thermal exposure. Alloying elements like copper $(\mathrm{Cu})$ and nickel $(\mathrm{Ni})$ are specifically added to maintain good mechanical properties at high temperatures [10-13]. These elements form intermetallic compounds that are thermally stable and can withstand load bearing during temperature rise. Using too much $\mathrm{Cu}$ will pollute the water and ground, causing the exposure of living beings to a higherlevel dose that may be harmful and lead to health problems. The aim is thus to the $\mathrm{Cu}$ amounts in the alloy design. [14]. 
Several studies focused on rare earths in the recent decade for their modifying effect on eutectic silicon $[15,16]$. Recently the role of lanthanum (La) and cerium (Ce) additions for the high-temperature performance of Al-based alloys became of interest [17-23].

In particular, Wang et al. [24] reported the formation of nanoscale ( $\mathrm{La}, \mathrm{Ce})$-based phases in an Al-Si-Mg-Zn alloy. The rapid solidification in high-pressure die-casting determines the presence of nano-precipitates in the $\mathrm{Al}$ matrix in the as-cast condition. The thermal stability of these phases improves the high-temperature performance and is not affected by heat treatment.

Previous work on tensile properties by Du et al. [17] reported a significant strength increase in the $200-400{ }^{\circ} \mathrm{C}$ temperature range. They concluded that the strengthening effects related to the formation of $\mathrm{Al}_{11}(\mathrm{La}, \mathrm{Ce})_{3}$ are primarily load-bearing and have modulus mismatch. Besides, the sustainability-performance-cost benefit analysis by Jarfors et al. [25] demonstrated that it is critical to consider the reinforcing effect of the alloying elements to perform an informed choice. Rare earths such as La and Ce become advantageous in terms of environmental impact and cost benefits compared to $\mathrm{Mg}$.

The addition of $\mathrm{La}, \mathrm{Ce}$, and $\mathrm{Ni}$ and $\mathrm{Cu}$ into the matrix improves the mechanical property at elevated temperatures by forming intermetallic phases. Due to the hardness and modulus of phases formed not being well-studied, the present work aims to assess the hardness and elastic properties of the phases that constitute the $\mathrm{Al} / \mathrm{SiCp}$ composites adapted for elevated temperatures. This investigation compared materials with and without the addition of transition metals $(\mathrm{Ni}$ and $\mathrm{Cu}$ ) and rare earths ( $\mathrm{La}$ and $\mathrm{Ce}$ ) to the matrix alloy.

The present study aims to gain a comprehensive knowledge of the Al/SiCp composites to improve the strength at elevated temperatures to be applied in the brake disk for highspeed trains and electric vehicles. The targeted maximum service temperatures well above $420{ }^{\circ} \mathrm{C}$. The friction and wear performance are better than the grey cast iron, and their use can reduce density by $60 \%$ and improve the thermal conductivity $[5,26]$.

\section{Materials and Methods}

\subsection{Material Production}

In the current study, two different $\mathrm{Al} / \mathrm{SiCp}$ composites denominated $\mathrm{C} 0$ and $\mathrm{C} 1$ with matrix compositions collated in Table 1, were investigated. It should be noted that La and $\mathrm{Ce}$ are given as nominal values due to the limitations of the analysis equipment.

Table 1. Chemical composition of matrix alloys [wt.\%].

\begin{tabular}{ccccccccccc}
\hline Matrix Alloy & $\mathbf{S i}$ & $\mathbf{C u}$ & $\mathbf{N i}$ & $\mathbf{F e}$ & $\mathbf{M n}$ & $\mathbf{T i}$ & $\mathbf{M g}$ & $\mathbf{C e}$ & $\mathbf{L a}$ & $\mathbf{A l}$ \\
\hline $\mathrm{C} 0$ & 10 & 0.2 & - & 0.1 & - & 0.1 & 0.8 & - & - & bal. \\
$\mathrm{C} 1$ & 10 & 1.9 & 1.9 & 0.1 & 0.8 & 0.1 & 0.8 & 1 & 1 & bal. \\
\hline
\end{tabular}

The $\mathrm{Al} / \mathrm{SiCp}$ materials were processed by a proprietary stir-casting method to keep porosity at a minimum level. The carbides were heat-treated at $1000^{\circ} \mathrm{C}$ for one hour to grow silicon oxide $\left(\mathrm{SiO}_{2}\right)$ on the surface of particles. The wetting angle between $\mathrm{SiO}_{2}$ and molten $\mathrm{Al}$ at that temperature will be below 68.8 degrees, leading to evenly dispersed $\mathrm{SiC}$ particles in the molten alloy [27]. The fraction of the reinforcing carbides was $\sim 14 \mathrm{wt} . \%$.

\subsection{Microstructural Characterisation}

Samples were mounted and prepared for metallographic observation combining the grinding steps for hard materials, $\mathrm{SiC}$ particles, and the polishing steps for soft materials, AlSi matrix. Metallographic observations were performed by Olympus DSX1000 (Olympus Corporation, Shinjuku, Japan), optical microscope (OM) and JSM-7001F (JEOL, Akishima, Japan) scanning electron microscope (SEM). Octane Pro (Edax, Mahwah, NJ, USA) probe for energy X-ray dispersion spectroscopy (EDS) was employed for phase recognition. 


\subsection{Microstructure Mechanical Properties Characterisation}

Nanoindentation was performed with the diamond Berkovich indenter (NanoTestTM, Micro Materials Ltd., Wrexham, UK). The tests were carried out on unetched specimens to detect the actual surface hardness. For each material, the applied load was $10 \mathrm{mN}$ over a grid of $20 \times 20$ indentations distanced $15 \mu \mathrm{m}$.

The hardness $H_{I T}[\mathrm{GPa}]$ come from Equation (1):

$$
H_{I T}=P_{\max } / A_{c}
$$

The $P_{\max }[\mathrm{mN}]$ is the peak load, and the $A_{c}\left[\mathrm{~nm}^{2}\right]$ is the indenter contact surface projected area on the tested material.

The reduced modulus $E_{r}[\mathrm{GPa}]$ come from Equation (2):

$$
E_{r}=\sqrt{\pi} \cdot S / 2 \cdot \sqrt{A_{c}}
$$

In Equation (2), $S[\mathrm{mN} / \mathrm{nm}$ ] is the experimentally measured stiffness of the upper portion of the elastic unloading, which can be determined by calculating the slope of the load-displacement curve at the beginning of the unloading process. The elastic modulus $E_{I T}[\mathrm{GPa}]$ was calculated from the reduced modulus $E_{r}$ [GPa] with Equation (3):

$$
E_{I T}=\left(1-v^{2}\right) /\left(\frac{1}{E_{r}}-\frac{1-v_{i}^{2}}{E_{i}}\right)
$$

In Equation (3), $E_{i}=1141 \mathrm{GPa}$ is the elastic modulus of the diamond indenter, $v_{i}=0.07$ is the Poisson's ratio of the diamond indenter, and $v$ is the Poisson's ratio of the tested material [28]. In the present study, $v=0.18$ for the $\mathrm{SiC}$ and $v=0.3$ for the other phases [29].

\section{Results and Discussion}

This section may be divided by subheadings. It should provide a concise and precise description of the experimental results, their interpretation, and the experimental conclusions that can be drawn.

\subsection{Microstructure and Identification of Intermetallic Phases}

Figure 1 presents the SEM micrograph and related EDS element map for Material C0. The EDS data were used to identify the secondary phases formed in the matrix alloy.
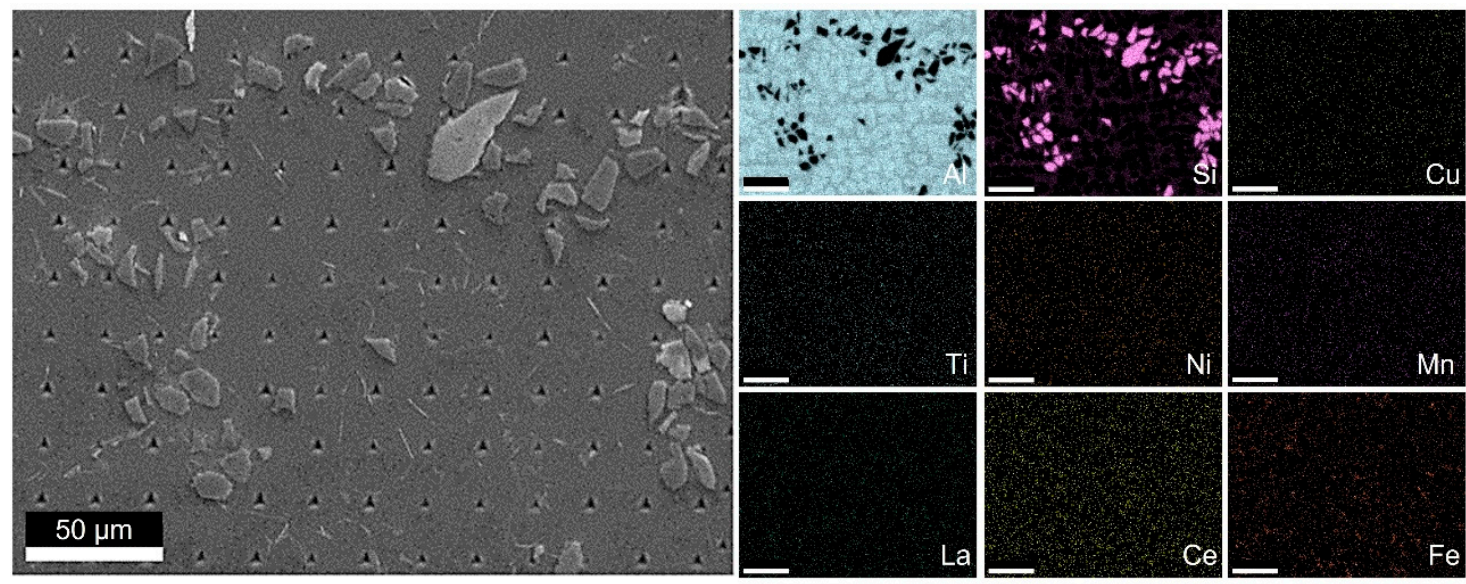

Figure 1. Scanning electron microscopy (SEM) image plus energy-dispersive X-ray spectroscopy (EDS) mapping: Material C0. 
Figure 2 shows the SEM micrograph and related EDS element map for Material C1. In addition to the $\mathrm{Al}$ matrix, the eutectic $\mathrm{Si}$ and the $\mathrm{SiC}$ particles, various secondary phases were present with different morphologies.
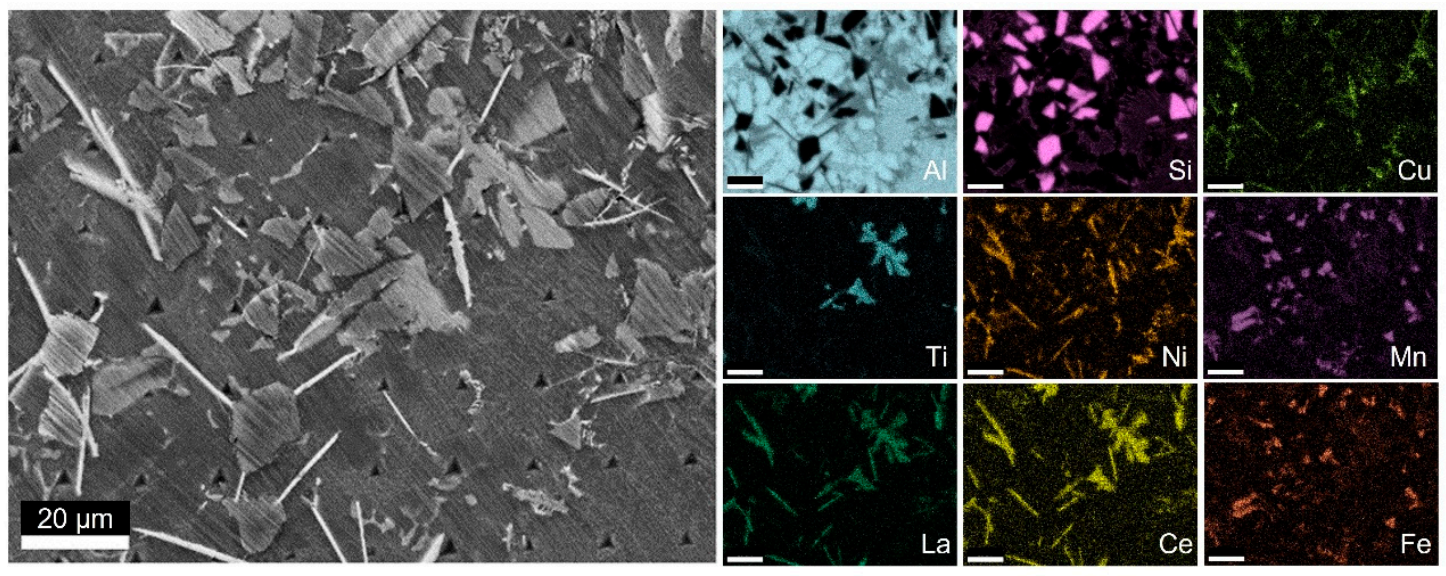

Figure 2. SEM image and EDS mapping: Material C1.

Table 2 summarises the at.\% content range of the elements in the secondary phases identified with EDS. The values given in Table 2 were compared with the atomic composition reported in the literature [30-35]. The Al content can be higher than expected from the nominal composition because of the interaction volume of the matrix with the electric beam, with an acceleration voltage of $20 \mathrm{kV}$.

Table 2. Chemical composition range [at.\%] of intermetallic phases from EDS spectra.

\begin{tabular}{|c|c|c|c|c|c|c|c|c|c|c|c|c|}
\hline $\begin{array}{c}\text { Assigned } \\
\text { Phase/ } \\
\text { Morphology }\end{array}$ & Composition & Al & $\mathrm{Si}$ & $\mathrm{Fe}$ & $\mathrm{Mg}$ & Mn & $\mathbf{L a}$ & $\mathrm{Ce}$ & $\mathrm{Ti}$ & $\mathrm{Ni}$ & $\mathrm{Cu}$ & Material \\
\hline \multirow{2}{*}{$\begin{array}{c}\pi- \\
\mathrm{Al}_{8} \mathrm{FeMg}_{3} \mathrm{Si}_{6} / \\
\text { lath }\end{array}$} & detected & $72.5-75.3$ & $14.4-17.9$ & $1.2-2.1$ & $7.6-9.2$ & - & - & - & - & - & - & $\mathrm{CO}$ \\
\hline & nominal & 44.4 & 33.3 & 5.5 & 16 & - & - & - & - & - & - & \\
\hline \multirow{2}{*}{$\begin{array}{c}\alpha- \\
\mathrm{Al}_{15}(\mathrm{Fe}, \mathrm{Mn})_{3} \mathrm{Si}_{2} / \\
\text { polygonal }\end{array}$} & detected & $70.0-71.6$ & $10.0-11.8$ & $3.5-3.54$ & - & $11.7-12.0$ & - & - & - & $1.47-1.5$ & - & $\mathrm{C} 1$ \\
\hline & nominal & 65.2 & 8.6 & 13 & - & 13 & - & - & - & - & - & \\
\hline \multirow{2}{*}{$\begin{array}{c}\mathrm{Al}_{20}(\mathrm{Ce}, \mathrm{La}) \mathrm{Ti}_{2} / \\
\text { polygonal }\end{array}$} & detected & $82.1-83.6$ & $3.8-6.1$ & - & - & - & $1.9-2.1$ & $2.5-2.7$ & $6.8-7.2$ & - & $0.69-0.74$ & $\mathrm{C} 1$ \\
\hline & nominal & 83.3 & - & - & - & - & 4.1 & 4.1 & 8.2 & - & - & \\
\hline \multirow{2}{*}{$\begin{array}{c}\mathrm{Al}_{11}(\mathrm{Ce}, \mathrm{La})_{3} / \\
\text { lath }\end{array}$} & detected & $58.0-65.9$ & $15.8-18.1$ & - & - & - & $1.0-4.8$ & $0.8-4.0$ & - & $3-12.2$ & $1.6-6.6$ & $\mathrm{C} 1$ \\
\hline & nominal & 64.7 & - & - & - & - & 17 & 17 & - & - & - & \\
\hline
\end{tabular}

The lath phase containing Fe and $\mathrm{Mg}$ was identified as the $\pi-\mathrm{Al}_{8} \mathrm{FeMg}_{3} \mathrm{Si}_{6}$ phase, in line with Casari et al. [30] and Ludwig et al. [31]. The excessive Al content, compared to the nominal composition, is linked to the interaction volume of the electron beam during the measurement and the size of the phase. The composition of the polygonal phase containing Fe and $\mathrm{Mn}$ corresponds to the $\alpha-\mathrm{Al}_{15}(\mathrm{Fe}, \mathrm{Mn})_{3} \mathrm{Si}_{2}$ phase, with a small quantity of dissolved $\mathrm{Ni}$ according to Khalifa et al. [32]. The Ti(La,Ce)-based phase with polygonal morphology can be the $\mathrm{Al}_{3} \mathrm{Ti}$ phase with $\mathrm{La}$ and $\mathrm{Ce}$ dissolved in the lattice. The crystal structure is tetragonal with six $\mathrm{Al}$ atoms and two Ti atoms in each unit cell, but the at.\% content of Ti does not align with the composition in Table 2. Melotti et al. [33] reported the formation of the $\mathrm{Al}_{20} \mathrm{CeTi}_{2}$ phase in a cast $\mathrm{Al}-\mathrm{MMC}$. The polygonal morphology and the composition in at.\% align with those found in the present study (Table 2). This intermetallic has a face-centred cubic structure (cF184) [36], like the $\mathrm{Al}_{20} \mathrm{LaTi}_{2}$ phase [35,37]. Given the similar atomic structure of $\mathrm{La}$ and $\mathrm{Ce}$, the phase in the present work can be identified as $\mathrm{Al}_{20}(\mathrm{La}, \mathrm{Ce}) \mathrm{Ti}_{2}$.

The $\mathrm{Al}(\mathrm{La}, \mathrm{Ce})$-based phase with lath morphology was identified as $\mathrm{Al}_{11}(\mathrm{La}, \mathrm{Ce})_{3}$ according to previous work by $\mathrm{Du}$ et al. [17], who reported that $\mathrm{Cu}$ and $\mathrm{Ni}$ are partially 
dissolved in this intermetallic phase. The presence of $\mathrm{Ni}$ in the $\mathrm{Al}_{11} \mathrm{Ce}_{3}$ phase was further confirmed by the Springer Material database [34], and it also explains the presence of $\mathrm{Cu}$. The lattice structure is body-centred orthorhombic (oI28), and the inter-changeability of La and $\mathrm{Ce}$ in the $\mathrm{Al}_{11} \mathrm{X}_{3}$ structure was confirmed by Medvedev et al. [38].

Figure $3 a, b$ show the same regions of Figures 1 and 2, respectively. The colours of the phases in the optical microscope image are different, and it helped distinguish them, as depicted in Figure 3. Figure 3a shows the microstructure of Material C0, while Figure $3 b$ depicts the material with transition elements $(\mathrm{Cu}$ and $\mathrm{Ni}$ ) and rare-earth elements ( $\mathrm{La}$ and $\mathrm{Ce}$ ) in the matrix alloy and the different phases listed in Table 2 showed different colours. The $\alpha$-Al matrix appeared bright grey, and the black particles were the reinforcing carbides.
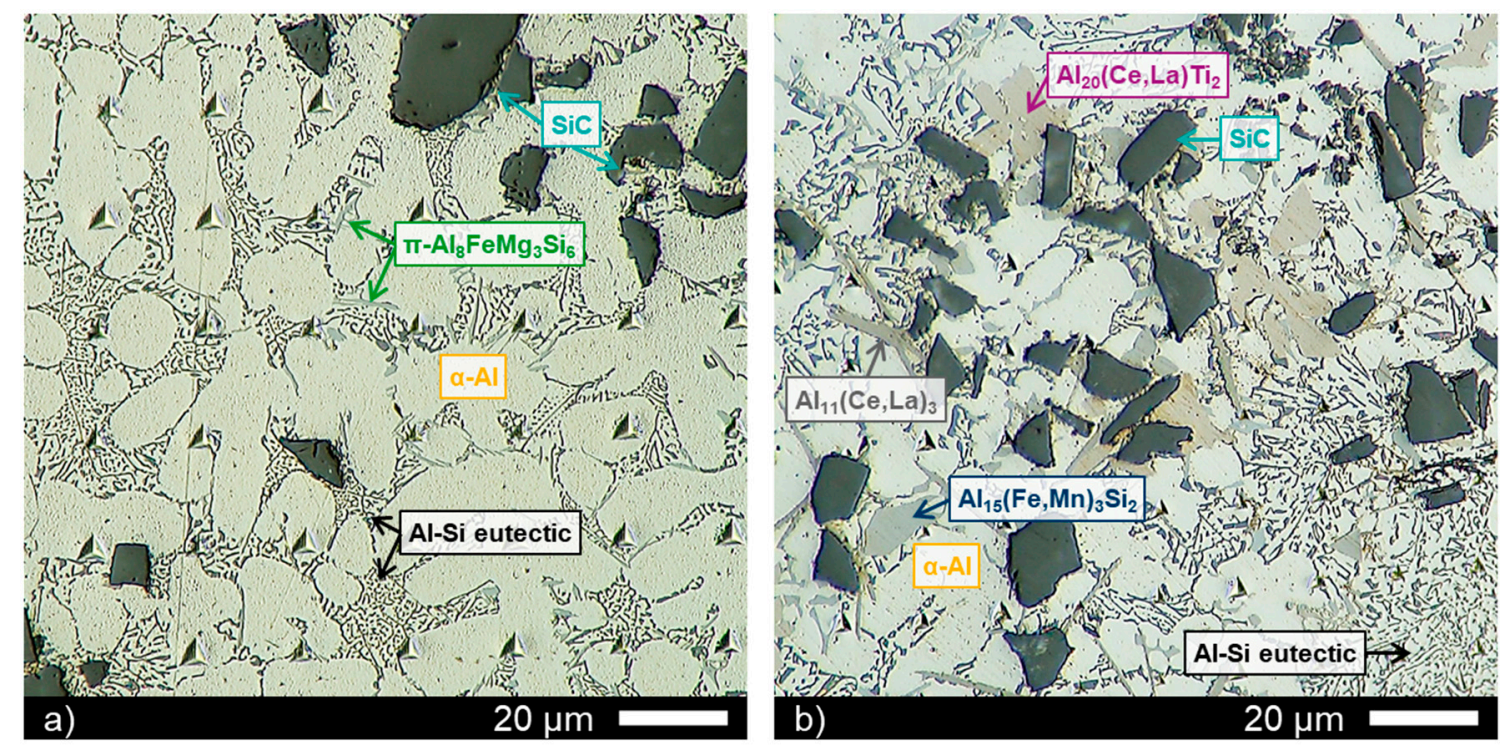

Figure 3. Optical microscope micrographs: (a) Material C0; (b) Material C1.

\subsection{Microstructure Mechanical Properties}

The displacement indentation curves included loading and unloading ramps. During the initial loading, both elastic and plastic deformation processes occurred. A slight elastic deformation recovery occurred at the unloading section, as the elastic and plastic responses of the material determined the indenter penetration depth. The hardness is correlated with the indenter penetration depth, whereas the elastic modulus is correlated with the elastic response of the phases.

The indentation curves of the two materials are shown in Figure 4. Figure 4a represents the curves of the four phases in Material C0: $\alpha-\mathrm{Al}, \mathrm{SiC}, \mathrm{Al}-\mathrm{Si}$ eutectic, and $\pi-\mathrm{Al}_{8} \mathrm{FeMg}_{3} \mathrm{Si}_{6}$. Figure $4 \mathrm{~b}$ represents the curves of the six phases in Material C1: $\alpha$-Al, SiC, Al-Si eutectic, $\alpha-\mathrm{Al}_{15}(\mathrm{Fe}, \mathrm{Mn})_{3} \mathrm{Si}_{2}, \mathrm{Al}_{20}(\mathrm{La}, \mathrm{Ce}) \mathrm{Ti}_{2}$, and $\mathrm{Al}_{11}(\mathrm{La}, \mathrm{Ce})_{3}$. The indentation depth varied with the phases, and it was caused by the elastic and plastic response of the material.

In Figure $4 \mathrm{a}$, the $\alpha$-Al curve (yellow) shows $\sim 600 \mathrm{~nm}$ maximum indentation depth, and the loading ramp had a low slope, which means it was the softest phase. The maximum indentation depth of $\mathrm{SiC}$ (light blue curve) was $110 \mathrm{~nm}$, and the slope of the loading ramp was steep, which means it was the hardest phase. The Al-Si eutectic (black curve) and the $\pi-\mathrm{Al}_{8} \mathrm{FeMg}_{3} \mathrm{Si}_{6}$ (green curve) phases presented a maximum indentation depth of $\sim 500 \mathrm{~nm}$ and $\sim 420 \mathrm{~nm}$. The higher hardness of SiC phases shown short indentation depth, and the soft $\alpha$-Al matrix had the deepest indentation depth. The sequence of indentation depth corresponded opposite to the hardness of the phases.

Figure $4 \mathrm{~b}$ shows the curves of the $\alpha-\mathrm{Al}_{15}(\mathrm{Fe}, \mathrm{Mn})_{3} \mathrm{Si}_{2}$ (blue curve) phase and the (La,Ce)-based phases, $\mathrm{Al}_{20}(\mathrm{La}, \mathrm{Ce}) \mathrm{Ti}_{2}$ (purple curve) and $\mathrm{Al}_{11}(\mathrm{La}, \mathrm{Ce})_{3}$ (grey curve). At the loading curve of the $\mathrm{SiC}, \mathrm{Al}_{20}(\mathrm{La}, \mathrm{Ce}) \mathrm{Ti}_{2}, \mathrm{Al}-\mathrm{Si}$ eutectic and $\alpha$-Al phases shown a discontinue so-called "pop-in" effect, which could be explained by dislocation activities [39]. 
The displacement changes at the load are related to the tested material's maximum shear strength, and it is linked to the nucleation and propagation of dislocation.

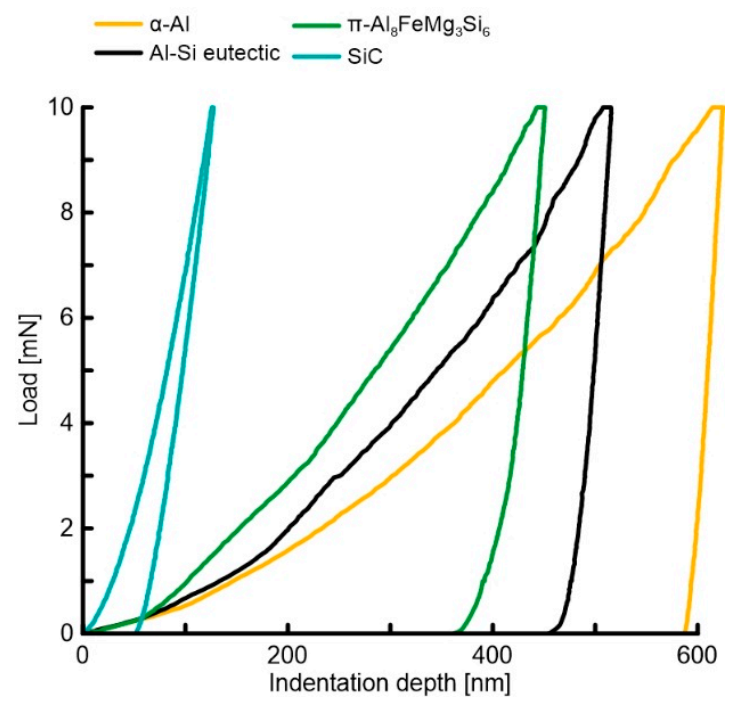

(a)

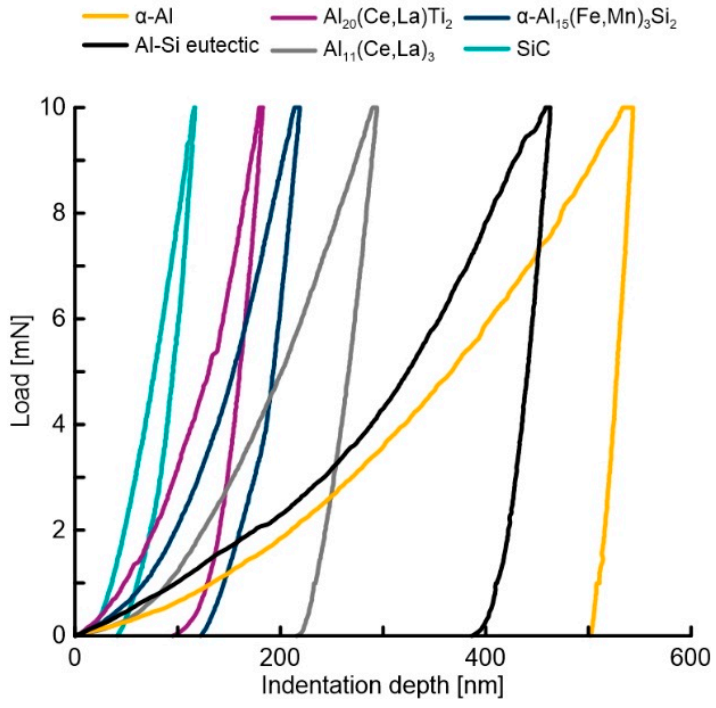

(b)

Figure 4. Plots of load vs. indentation depth for each phase: (a) Material C0; (b) Material C1.

Table 3 lists the hardness of the phases in materials $\mathrm{C} 0$ and $\mathrm{C} 1$. The hardness of $\alpha-\mathrm{Al}$ in $\mathrm{C} 0$ and $\mathrm{C} 1$ composites are $0.98 \mathrm{GPa}$ and $1.24 \mathrm{GPa}$, respectively, and the pure $\mathrm{Al}$ is $0.7 \mathrm{GPa}[40,41]$. The hardness of $\alpha-\mathrm{Al}$ in $\mathrm{C} 1$ material is slightly higher than the $\mathrm{C} 0$ alloy. This value is in line with previous studies by Nayak et al. [42] and Youn et al. [43], who investigated Al-7Si alloys with $0.1-0.4 \mathrm{wt} . \%$ of $\mathrm{Mg}$. The increase in hardness of the $\alpha-\mathrm{Al}$ is due to the strengthening effect of the solid solution of $\mathrm{Si}, \mathrm{Cu}$ and $\mathrm{Mg}$ in the present study. This effect was confirmed by comparing the values of 1.45-1.55 GPa reported by Tupaj et al. [44] and Chen et al. [40,41]. Both studies investigated hyper-eutectic Al-Si alloys with high contents of $\mathrm{Cu}$ and $\mathrm{Mg}$ in the 1.4-2 wt.\% and 0.9-1.33 wt.\% ranges, respectively. In line with what was observed for the $\alpha-\mathrm{Al}$, the hardness value of the Al-Si eutectic is $1.51 \pm 0.04 \mathrm{GPa}$ in Material C0, and it is $2.00 \pm 0.13 \mathrm{GPa}$ in Material C1.

Table 3. Hardness and elastic modulus of phases formed in materials C0 and C1.

\begin{tabular}{cccc}
\hline Phase & Composite & Hardness/GPa & Elastic Modulus/GPa \\
\hline \multirow{2}{*}{$\alpha-\mathrm{Al}$} & $\mathrm{C} 0$ & $0.98 \pm 0.01$ & $88.2 \pm 1.5$ \\
& $\mathrm{C} 1$ & $1.24 \pm 0.05$ & $93.9 \pm 3.4$ \\
\hline \multirow{2}{*}{$\mathrm{Al}-\mathrm{Si}$ eutectic } & $\mathrm{C} 0$ & $1.51 \pm 0.04$ & $97.2 \pm 3.2$ \\
& $\mathrm{C} 1$ & $2.00 \pm 0.13$ & $106.4 \pm 5.1$ \\
\hline \multirow{2}{*}{$\mathrm{SiC}$} & $\mathrm{C} 0$ & $27.7 \pm 2.6$ & $335.2 \pm 30.7$ \\
& $\mathrm{C} 1$ & $30.2 \pm 2.3$ & $402.5 \pm 45.0$ \\
$\pi-\mathrm{Al}_{8} \mathrm{FeMg}{ }_{3} \mathrm{Si}_{6}$ & $\mathrm{C} 0$ & $2.1 \pm 0.6$ & $111.0 \pm 44.0$ \\
$\mathrm{Al}_{20}(\mathrm{Ce}, \mathrm{La}) \mathrm{Ti}_{2}$ & $\mathrm{C} 1$ & $6.8 \pm 0.8$ & $148.1 \pm 13.6$ \\
$\mathrm{Al}_{2}(\mathrm{La}, \mathrm{Ce}) 3$ & $\mathrm{C} 1$ & $2.8 \pm 0.6$ & $124.3 \pm 27.4$ \\
$\alpha-\mathrm{Al}_{15}(\mathrm{Fe}, \mathrm{Mn})_{3} \mathrm{Si}_{2}$ & $\mathrm{C} 1$ & $8.4 \pm 3.0$ & $158.0 \pm 32.8$ \\
\hline
\end{tabular}

Moving to the intermetallic phases, the $\pi-\mathrm{Al}_{8} \mathrm{FeMg}_{3} \mathrm{Si}_{6}$ phase in Material $\mathrm{C} 0$ showed a hardness value of $2.14 \pm 0.56 \mathrm{GPa}$, which contrasts with the Vickers hardness of $6.85 \mathrm{GPa}$ reported by Farkoosh et al. [45] from a non-clarified reference. The direct comparison between Berkovich and Vickers indentations can be performed only after careful conversion [46]. In Material $\mathrm{C} 1$, several intermetallic phases were detected, and the $\alpha-\mathrm{Al}_{15}(\mathrm{Fe}, \mathrm{Mn})_{3} \mathrm{Si}_{2}$ showed a hardness of $8.44 \pm 3.04 \mathrm{GPa}$. Once again, this value is lower than the data available 
in the literature. Tupaj et al. [44] reported $\sim 14.7 \pm 2.0 \mathrm{GPa}$ for the $\mathrm{Al}(\mathrm{Fe}, \mathrm{Mn}) \mathrm{Si}$ phase supersaturated with $\mathrm{Cr}$ and V, while Chen et al. [40,41] reported $10.8 \pm 0.3 \mathrm{GPa}$. They also observed that hardness was constant with increasing concentrations of Fe and $\mathrm{Mn}$, from 14.21 to 23.13 at. \% of $\mathrm{Fe}+\mathrm{Mn}$.

The hardness of the $\mathrm{Al}_{20}(\mathrm{La}, \mathrm{Ce}) \mathrm{Ti}_{2}$ phase was $6.78 \pm 0.76 \mathrm{GPa}$ and the $\mathrm{Al}_{11}(\mathrm{La}, \mathrm{Ce})_{3}$ showed $2.82 \pm 0.61 \mathrm{GPa}$. For the former phase, Ma et al. [35] calculated hardness $(\mathrm{H})$ by a semi-empirical relation in Equation (4) that combines bulk $(B)$ and shear $(G)$ moduli [GPa]:

$$
H=0.92 G^{0.708}(B / G)^{1.137}
$$

The resulting hardness values were 12.2 GPa for both $\mathrm{Al}_{20} \mathrm{CeTi}_{2}$ and $\mathrm{Al}_{20} \mathrm{LaTi}_{2}$, and this value is almost double the hardness measured in the present work. The authors derived the $\mathrm{Al}$ hardness with the same Equation (4) resulting in $2.87 \mathrm{GPa}$, a value double than the ones measured in the present work.

The hardness of $\mathrm{SiC}$ was in the range 27.7-30.3 GPa, and this was the hardest phase in the matrix. Therefore, the $\mathrm{SiC}$ particle could play a crucial role in protecting the matrix from wear damage.

Table 3 shows the elastic modulus of the different phases in Materials $\mathrm{C} 0$ and $\mathrm{C} 1$. The elastic modulus of newly formed phases in $\mathrm{C} 1$ alloy are $\mathrm{Al}_{20}(\mathrm{Ce}, \mathrm{La}) \mathrm{Ti}_{2}, \mathrm{Al}_{11}(\mathrm{La}, \mathrm{Ce})_{3}$ and $\alpha-\mathrm{Al}_{15}(\mathrm{Fe}, \mathrm{Mn})_{3} \mathrm{Si}_{2}$, their elastic modulus are $148.1 \pm 13.6 \mathrm{GPa}, 124.3 \pm 27.4 \mathrm{GPa}$, and $158.0 \pm 32.8 \mathrm{GPa}$, respectively. The elastic modulus of all three phases is higher than the phases in the $\mathrm{C} 0$ alloy, except the carbide.

Wang et al. [47] reported a modulus of 78.6-84.1 GPa for pure Al. In the present work, the modulus was $88.2 \pm 1.5 \mathrm{GPa}$ in material $\mathrm{C} 0$ and $93.9 \pm 3.4 \mathrm{GPa}$ in material $\mathrm{C} 1$, with a difference of $6 \%$. For the $\mathrm{Al}_{20}(\mathrm{Ce}, \mathrm{La}) \mathrm{Ti}_{2}$ phase, $\mathrm{Ma}$ et al. [35] reported a Poisson's ratio of 0.2 , an elastic modulus of 141-146 GPa. Updating the Poisson's value in Equation (1), the resulting elastic modulus is $156 \pm 14 \mathrm{MPa}$ instead of $163 \pm 14 \mathrm{MPa}$. Similar to what was observed for hardness, the elastic modulus of phases in $\mathrm{C} 1$ alloy is higher than the $\mathrm{C} 0$ alloy, which means the transition metals ( $\mathrm{Ni}$ and $\mathrm{Cu}$ ) and rare earth ( $\mathrm{La}$ and $\mathrm{Ce}$ ) contribute to the improvement of elastic modulus.

The design of automotive structure components made from $\mathrm{Al}$ alloys is usually based on requirements about yield strength and elastic modulus [48]. The aluminium's strength usually meets the requirement, while the elastic modulus usually does not. Introducing secondary phases with high modulus could improve the overall elastic modulus of the material.

The overall modulus of material usually depends on the volume fraction, modulus, size, distribution, and the interface between the secondary phases and matrix. Due to the difference of elastic modulus between particle and matrix, plastic deformation easily occurs mainly at the interface region and thus induces the increased density of dislocation. The increased elastic modulus of the phases contribute to the matrix of stresses [49]. It also improves the elastic modulus value of the matrix and can be estimated by theoretical modelling. The most frequently used mathematical model is the Halpin-Tsai model for particle-reinforced composites [50], expressed in Equation (5).

$$
E_{c}=\frac{E_{m}\left(1+2 s q V_{p}\right)}{1-q V_{p}}
$$

In Equation (5), $E_{c}$ and $E_{m}[\mathrm{GPa}]$ are the composite and matrix elastic moduli, respectively. The parameter $s$ is the aspect ratio of the reinforcing particles, $V_{p}[\%]$ is volume fraction, $q$ is a geometrical parameter estimated by Equation (6).

$$
q=\frac{\left(\frac{E_{p}}{E_{m}}\right)-1}{\left(\frac{E_{p}}{E_{m}}\right)+2 s}
$$


In Equation (6), $E_{p}[\mathrm{GPa}]$ is the elastic modulus of the reinforcing particles.

Equations (5) and (6) enable the calculation of SiC particle's contribution to the composite material's elastic modulus. The aspect ratio of $\mathrm{SiC}$ particles resulted in $s \sim 2$, and their volume fraction was $V_{p} \sim 14 \%$ in both cases. The elastic modulus of $\mathrm{SiC}$ in materials $\mathrm{C} 0$ and $\mathrm{C} 1$ were $335.2 \mathrm{GPa}$ and $402.5 \mathrm{GPa}$, respectively, according to Table 3 .

The rule of mixture was used to predict the modulus of the matrix alloys for materials $\mathrm{C} 0$ and $\mathrm{C} 1$. For reinforced composites, the elastic modulus $E_{m}$ of the composites can be calculated by Equations (7) and (8) [51]. Equation (7) is the upper-bound modulus and assumes that the reinforcing phases are parallel to the load direction and Equation (8) is representative of the lower-bound modulus, with the reinforced phases transverse to the load direction.

$$
\begin{aligned}
E_{m} & =f E_{f}+(1-f) E_{a} \\
E_{m} & =\left(\frac{f}{E_{f}}+\frac{1-f}{E_{a}}\right)^{-1}
\end{aligned}
$$

$E_{f}$ is the elastic modulus of phases, $E_{a}$ is the elastic modulus of the $\alpha-\mathrm{Al}, f$ is the volume fraction of the reinforcing phases. Thermocalc software was used to calculate the volume fraction of the phases in the matrix alloys of $\mathrm{C} 0$ and $\mathrm{C} 1$, and the result are listed in Table 4 . The matrix alloys can be seen as composite materials reinforced by the secondary phases, and thus their elastic moduli (Table 3) were used in Equations (7) and (8) to calculate the matrix moduli listed in Table 5.

Table 4. Fraction of phases, calculated by Thermocalc, formed in the matrix alloys of materials C0 and $\mathrm{C} 1$.

\begin{tabular}{ccc}
\hline Phase & Composite & Fraction \\
\hline \multirow{2}{*}{$\alpha-\mathrm{Al}$} & $\mathrm{C} 0$ & 0.89 \\
& $\mathrm{C} 1$ & 0.76 \\
\hline \multirow{2}{*}{$\mathrm{Al}-\mathrm{Si}$ eutectic } & $\mathrm{C} 0$ & 0.09 \\
& $\mathrm{C} 1$ & 0.08 \\
\hline \multirow{2}{*}{$\mathrm{SiC}$} & $\mathrm{C} 0$ & 0.14 \\
& $\mathrm{C} 1$ & 0.14 \\
\hline$\pi-\mathrm{Al}_{8} \mathrm{FeMg} \mathrm{Si}_{6}$ & $\mathrm{C} 0$ & 0.004 \\
$\mathrm{Al}_{20}\left(\mathrm{Ce}, \mathrm{La}^{2} \mathrm{Ti}_{2}\right.$ & $\mathrm{C} 1$ & 0.030 \\
$\mathrm{Al}_{11}(\mathrm{La}, \mathrm{Ce})_{3}$ & $\mathrm{C} 1$ & 0.037 \\
$\alpha-\mathrm{Al}_{15}(\mathrm{Fe}, \mathrm{Mn})_{3} \mathrm{Si}_{2}$ & $\mathrm{C} 1$ & 0.028 \\
\hline
\end{tabular}

Table 5. Calculated elastic moduli of matrix alloys and composites $\mathrm{C} 0$ and $\mathrm{C} 1$, with and without $\mathrm{SiC}_{\mathrm{p}}$. The rules of mixtures were used for the matrix alloys, and the Halpin-Tsai model was used for the composite materials.

\begin{tabular}{clcc}
\hline Composite & Rules of Mixture & Em [GPa] & Ec [GPa] \\
\hline \multirow{2}{*}{ C0 } & upper-bound modulus equation & 90.5 & 113.9 \\
& lower-bound modulus equation & 87.7 & 111.0 \\
\hline \multirow{2}{*}{ C1 } & upper-bound modulus equation & 105.1 & 133.1 \\
& lower-bound modulus equation & 93.4 & 120.9 \\
\hline
\end{tabular}

Table 5 lists the elastic moduli of the matrix alloys calculated with the upper and lower bound of the rule of mixture, defined in Equations (7) and (8). These values were used in the Halpin-Tsai model, expressed in Equation (5), to describe the composite materials.

As listed in Table 5, The $E_{m}$ of the matrix alloys C0 and C1 are 87.7-90.5 GPa and 93.4-105.1 GPa, respectively. The transition metals (Ni and $\mathrm{Cu}$ ) and rare-earth elements (La and Ce) determined a 5-15\% increase of the elastic modulus of the matrix alloy. After 
calculation with Equations (5) and (6), the elastic modulus of the composites Ec resulted in 111.0-113.9 GPa for material C0 and 120.9-133.1 GPa for material C1. This result highlights that the $\mathrm{SiC}$ particles increased the elastic modulus of the matrix by $10-15 \%$ in both composite materials. Equation (9) from Ceschini et al. [49] describes the strength contribution of the modulus mismatch:

$$
C_{M M} \approx 3 \sqrt{2} \cdot \beta \cdot \sqrt{b} \cdot G_{m}
$$

$C_{M M}$ resulted 1.47 MPa.from previous work [17]. With $\beta=0.5$ and the Burgers vector $b=0.286 \mathrm{~nm}$ for in $\mathrm{Al}$, the resulting shear modulus of the matrix is $G_{m}=41 \mathrm{GPa}$. This in turn corresponds to an elastic modulus of $107 \mathrm{GPa}$ corresponding to $E_{m}$. In the current work the upper bound estimate for $E_{m}$ was $105.1 \mathrm{GPa}$ for material $\mathrm{C} 1$, validating the rules of mixture usage as it is reasonable. This correspondence also confirms a significant dispersion hardening effect, strengthening the matrix to better match the $\mathrm{SiC}$ reinforcement in a brake disc application.

\section{Conclusions}

The present study investigated the influence of transition metals $(\mathrm{Cu}$ and $\mathrm{Ni})$ and rareearth elements ( $\mathrm{La}$ and $\mathrm{Ce}$ ) addition to the microstructure of an $\mathrm{Al} / \mathrm{SiCp}$ composite. The hardness and elastic modulus of the secondary phases were measured by nanoindentation. The following conclusions can be drawn:

- The addition of $\mathrm{La}$ and $\mathrm{Ce}$ formed the $\alpha-\mathrm{Al}_{15}(\mathrm{Fe}, \mathrm{Mn})_{3} \mathrm{Si}_{2}, \mathrm{Al}_{20}(\mathrm{La}, \mathrm{Ce}) \mathrm{Ti}_{2}$, and $\mathrm{Al}_{11}(\mathrm{La}, \mathrm{Ce})_{3}$ phases, and the transitions metals were dissolved in these intermetallic phases.

- The hardness and elastic modulus of the phases of $\mathrm{Al}_{11}(\mathrm{La}, \mathrm{Ce})_{3}$ are $2.8 \pm 0.6 \mathrm{GPa}$ and $124.3 \pm 27.4 \mathrm{GPa}$, respectively; $\mathrm{Al}_{20}(\mathrm{Ce}, \mathrm{La}) \mathrm{Ti}_{2}$ has hardness $6.78 \pm 0.78 \mathrm{GPa}$ and elastic modulus $148.1 \pm 13.6 \mathrm{GPa}$; the $\alpha-\mathrm{Al}_{15}(\mathrm{Fe}, \mathrm{Mn})_{3} \mathrm{Si}_{2}$ phase has hardness $8.44 \pm 3.04 \mathrm{GPa}$ and elastic modulus $158.0 \pm 32.8 \mathrm{GPa} ; \pi-\mathrm{Al}_{8} \mathrm{FeMg}_{3} \mathrm{Si}_{6}$ has hardness $2.1 \pm 0.6 \mathrm{GPa}$ and elastic modulus $111.0 \pm 44.0 \mathrm{GPa}$.

- Based on the rule-of-mixture, the calculate elastic modulus of the matrix alloys $\mathrm{C} 0$ and C1 are 87.7-90.5 GPa and 93.4-105.1 GPa.

- Based on the Halpin-Tsai model for particle-reinforced composites, the calculated elastic modulus ranges of $\mathrm{C} 0$ and $\mathrm{C} 1$ composite materials are 111.0-113.9 GPa and 120.9-133.1 GPa, respectively. The $\mathrm{SiC}$ particles increased the elastic modulus of the matrix by $10-15 \%$ in both composite materials.

Author Contributions: Conceptualisation, A.W.E.J. and J.Z.; methodology, A.D., L.L. and A.W.E.J.; investigation, A.D. and L.L.; resources, A.W.E.J. and J.Z.; writing-original draft preparation, A.D. and L.L.; writing—review and editing, A.W.E.J., J.Z., G.Y. and K.W.; supervision, A.W.E.J., J.Z., G.Y. and K.W.; project administration, A.W.E.J. and J.Z.; funding acquisition, A.W.E.J., J.Z. and L.L. All authors have read and agreed to the published version of the manuscript.

Funding: This research was funded by the 1000 Foreign Expert Programme (China) and by the Knowledge Foundation (Sweden) under the projects CompCAST Plus (contract \#20170066).

Institutional Review Board Statement: Not applicable.

Informed Consent Statement: Not applicable.

Data Availability Statement: Data available in a publicly accessible repository.

Acknowledgments: The authors acknowledge the staff at Jönköping University and CAM Science and Technology (Jiangle) Institute of Semi-Solid Metal Technology.

Conflicts of Interest: The authors declare no conflict of interest.

\section{References}

1. Mortensen, A.; Jin, I. Solidification processing of metal matrix composites. Int. Mater. Rev. 1992, 37, 101-128. [CrossRef]

2. Levaillant, C.; Suéry, M. The semi-solid processing of alloys and composites. JOM 1990, 42, 26. [CrossRef] 
3. Nguyen, T.; Suéry, M.; Favier, D. Influence of SiC particle volume fraction on the compressive behaviour of partially remelted AlSi-based composites. Mater. Sci. Eng. A 1994, 183, 157-167. [CrossRef]

4. Thanh, L.N.; Suéry, M. Compressive behaviour of partially remelted A356 alloys reinforced with SiC particles. Mater. Sci. Technol. 1994, 10, 894-902. [CrossRef]

5. Thomas, A.; Zervos, N.; Ekelund, A.; Awe, S.A. Simulation study on the thermomechanical behaviour of Al-MMC automotive brake discs. Eurobrake 2019, 2019, 1-12.

6. Awe, S.A. Developing material requirements for automotive brake disc. Mod. Concepts Mater. Sci. 2019, 2, 1-4. [CrossRef]

7. D'Errico, F.; Casari, D.; Alemani, M.; Perricone, G.; Tosto, M. Industrial semisolid casting process for secondary aluminium alloys for decarbonising lightweight parts in automotive sector. MATEC Web Conf. 2020, 326, 06007. [CrossRef]

8. Serrenho, A.C.; Norman, J.; Allwood, J.M. The impact of reducing car weight on global emissions: The future fleet in Great Britain. Philos. Trans. R. Soc. A Math. Phys. Eng. Sci. 2017, 375, 20160364. [CrossRef]

9. Kenworthy, J.R. Transport energy use and greenhouse gases in urban passenger transport systems: A study of 84 global cities. In Proceedings of the International Sustainability Conference, Fremantle, Australia, 17-19 September 2003.

10. Xia, F.; Gao, X.; Liang, M.; Guo, Y.; Li, J.; Yang, Z.; Wang, J.; Zhang, L. Effect of thermal exposure on microstructure and high-temperature fatigue life of Al-Si piston alloys. J. Mater. Res. Technol. 2020, 9, 12926-12935. [CrossRef]

11. Zuo, L.; Ye, B.; Feng, J.; Xu, X.; Kong, X.Y.; Jiang, H. Effect of $\delta$-Al3CuNi phase and thermal exposure on microstructure and mechanical properties of Al-Si-Cu-Ni alloys. J. Alloys Compd. 2019, 791, 1015-1024. [CrossRef]

12. Zamani, M.; Morini, L.; Ceschini, L.; Seifeddine, S. The role of transition metal additions on the ambient and elevated temperature properties of Al-Si alloys. Mater. Sci. Eng. A 2017, 693, 42-50. [CrossRef]

13. Zhang, J.-Y.; Zuo, L.-J.; Feng, J.; Ye, B.; Kong, X.-Y.; Jiang, H.-Y.; Ding, W.-J. Effect of thermal exposure on microstructure and mechanical properties of $\mathrm{Al}-\mathrm{Si}-\mathrm{Cu}-\mathrm{Ni}-\mathrm{Mg}$ alloy produced by different casting technologies. Trans. Nonferrous Met. Soc. China 2020, 30, 1717-1730. [CrossRef]

14. Gaetke, L.M.; Chow-Johnson, H.S.; Chow, C.K. Copper: Toxicological relevance and mechanisms. Arch. Toxicol. 2014, 88, 1929-1938. [CrossRef]

15. Li, L.; Li, D.; Mao, F.; Feng, J.; Zhang, Y.; Kang, Y. Effect of cooling rate on eutectic Si in Al-7.0Si-0.3Mg alloys modified by La additions. J. Alloys Compd. 2020, 826, 154206. [CrossRef]

16. Gursoy, O.; Timelli, G. Lanthanides: A focused review of eutectic modification in hypoeutectic Al-Si alloys. J. Mater. Res. Technol. 2020, 9, 8652-8666. [CrossRef]

17. Du, A.; Jarfors, A.; Zheng, J.; Wang, K.; Yu, G. The Influence of La and Ce on Microstructure and Mechanical Properties of an Al-Si-Cu-Mg-Fe Alloy at High Temperature. Metals 2021, 11, 384. [CrossRef]

18. Zhao, B.; Zhan, Y.; Tang, H. High-temperature properties and microstructural evolution of Al-Cu-Mn-RE (La/Ce) alloy designed through thermodynamic calculation. Mater. Sci. Eng. A 2019, 758, 7-18. [CrossRef]

19. Sims, Z.C.; Rios, O.R.; Weiss, D.; Turchi, P.E.A.; Perron, A.; Lee, J.R.I.; Li, T.T.; Hammons, J.A.; Bagge-Hansen, M.; Willey, T.M.; et al. High performance aluminum-cerium alloys for high-temperature applications. Mater. Horiz. 2017, 4, 1070-1078. [CrossRef]

20. Aghaie, E. Effect of Cerium Addition on Improvement of Mechanical Properties of B319 Powertrain Aluminum Alloy. Master's Thesis, University of British Columbia, Kelowna, BC, Canada, 2019.

21. Elgallad, E.M.; Ibrahim, M.F.; Doty, H.W.; Samuel, F.H. Microstructural characterisation of Al-Si cast alloys containing rare earth additions. Philos. Mag. 2018, 98, 1337-1359. [CrossRef]

22. Liao, H.-C.; Xu, H.-T.; Hu, Y.-Y. Effect of RE addition on solidification process and high-temperature strength of $\mathrm{Al}-12 \% \mathrm{Si}-4 \%$ $\mathrm{Cu}-1.6 \% \mathrm{Mn}$ heat-resistant alloy. Trans. Nonferrous Met. Soc. China 2019, 29, 1117-1126. [CrossRef]

23. Hu, B.; Quan, B.; Li, D.; Wang, X.; Li, Z.; Zeng, X. Solid solution strengthening mechanism in high pressure die casting Al-Ce-Mg alloys. Mater. Sci. Eng. A 2021, 812, 141109. [CrossRef]

24. Wang, D.; Zhang, X.; Xu, S.; Nagaumi, H.; Li, X. Improvement of mechanical properties in micro-alloying Al-Si-Mg-Zn cast alloy. Mater. Lett. 2021, 283, 128810. [CrossRef]

25. Jarfors, A.E.; Du, A.; Yu, G.; Zheng, J.; Wang, K. On the sustainable choice of alloying elements for strength of aluminum-based alloys. Sustainability 2020, 12, 1059. [CrossRef]

26. Oladijo, O.P.; Awe, S.A.; Akinlabi, E.T.; Phiri, R.R.; Collieus, L.L.; Phuti, R.E. High-temperature properties of metal matrix composites. Encycl. Mater. Compos. 2021, 360-374. [CrossRef]

27. Laurent, V.; Chatain, D.; Eustathopoulos, N. Wettability of $\mathrm{SiO}_{2}$ and soxidised $\mathrm{SiC}$ by aluminium. Mater. Sci. Eng. 1991, 135, 89-94. [CrossRef]

28. Simmons, G.; Wang, H. Single Crystal Elastic Constants and Calculated Aggregate Properties. A Handbook, 2nd ed.; MIT Press: Cambridge, MA, USA, 1971; ISBN 0262190923.

29. Dostal, C.A. Engineered Materials Handbook; ASM International: Metals Park, OH, USA, 1989.

30. Casari, D.; Ludwig, T.H.; Merlin, M.; Arnberg, L.; Garagnani, G.L. The effect of Ni and V trace elements on the mechanical properties of A356 aluminium foundry alloy in as-cast and T6 heat treated conditions. Mater. Sci. Eng. A 2014, 610, 414-426. [CrossRef]

31. Ludwig, T.H.; Schaffer, P.L.; Arnberg, L. Influence of some trace elements on solidification path and microstructure of Al-Si foundry alloys. Met. Mater. Trans. A 2013, 44, 3783-3796. [CrossRef] 
32. Khalifa, W.; Samuel, F.H.; Gruzleski, J.E. Iron intermetallic phases in the Al corner of the Al-Si-Fe system. Met. Mater. Trans. A 2003, 34, 807-825. [CrossRef]

33. Melotti, F.; Dustan, A.; Hirst, T.; Griffiths, W.D. Effects of Ce on the thermal stability of the $\Omega$ phase in a cast aluminum metal matrix composite. Adv. Sci. Eng. Cast. Solidif. 2015, 137-144. [CrossRef]

34. Al11Ce3(Ce3Ni0.25Al10.75) Crystal Structure: Datasheet from "PAULING FILE Multinaries Edition-2012" in Springer Materials. Available online: https://materials.springer.com/isp/crystallographic/docs/sd_1821909 (accessed on 19 August 2021).

35. Ma, H.; Zhang, X.; Liu, C.; Zhao, L.; Jiang, W. Structural, elastic, anisotropic and thermodynamic properties of the caged intermetallics $\mathrm{RETi}_{2} \mathrm{Al}_{20}$ (RE = La, Ce, Gd and Ho): A first-principles study. Solid State Sci. 2019, 89, 121-129. [CrossRef]

36. CeTi2Al20 Crystal Structure: Datasheet from “PAULING FILE Multinaries Edition-2012". Available online: https://materials. springer.com/isp/crystallographic/docs/sd_1934769 (accessed on 19 August 2021).

37. LaTi2Al20 Crystal Structure: Datasheet from “PAULING FILE Multinaries Edition-2012". Available online: https:/ / materials. springer.com/isp/crystallographic/docs/sd_1013350 (accessed on 19 August 2021).

38. Medvedev, A.E.; Murashkin, M.Y.; Enikeev, N.A.; Bikmukhametov, I.; Valiev, R.Z.; Hodgson, P.D.; Lapovok, R. Effect of the eutectic $\mathrm{Al}-(\mathrm{Ce}, \mathrm{La})$ phase morphology on microstructure, mechanical properties, electrical conductivity and heat resistance of Al-4.5(Ce, La) alloy after SPD and subsequent annealing. J. Alloys Compd. 2019, 796, 321-330. [CrossRef]

39. Gouldstone, A.; Chollacoop, N.; Dao, M.; Li, J.; Minor, A.; Shen, Y. Indentation across size scales and disciplines: Recent developments in experimentation and modeling. Acta Mater. 2007, 55, 4015-4039. [CrossRef]

40. Chen, C.-L.; Richter, A.; Thomson, R. Mechanical properties of intermetallic phases in multi-component Al-Si alloys using nanoindentation. Intermetallics 2009, 17, 634-641. [CrossRef]

41. Chen, C.-L.; Richter, A.; Thomson, R. Investigation of mechanical properties of intermetallic phases in multi-component Al-Si alloys using hot-stage nanoindentation. Intermetallics 2010, 18, 499-508. [CrossRef]

42. Nayak, S.; Riester, L.; Dahotre, N.B. Instrumented indentation probing of laser surface-refined cast Al alloy. J. Mater. Res. 2004, 19, 202-207. [CrossRef]

43. Youn, S.; Seo, P.; Kang, C. A study on nano-deformation behavior of rheo-formed Al-Si alloy based on depth-sensing indentation with three-dimensional surface analysis. J. Mater. Process. Technol. 2005, 162-163, 260-266. [CrossRef]

44. Tupaj, M.; Orłowicz, A.W.; Mróz, M.; Trytek, A.; Dolata, A.J.; Dziedzic, A. A study on material properties of intermetallic phases in a multicomponent hypereutectic al-si alloy with the use of nanoindentation testing. Materials 2020, 13, 5612. [CrossRef] [PubMed]

45. Farkoosh, A.R.; Javidani, M.; Hoseini, M.; Larouche, D.; Pekguleryuz, M. Phase formation in as-solidified and heat-treated Al-Si-Cu-Mg-Ni alloys: Thermodynamic assessment and experimental investigation for alloy design. J. Alloys Compd. 2013, 551, 596-606. [CrossRef]

46. Nanomechanics Inc., Nano- versus Micro- Indentation Hardness. Available online: https://nanomechanicsinc.com/indentationhardness / (accessed on 19 August 2021).

47. Wang, J.; Du, Y.; Shang, S.-L.; Liu, Z.-K.; Li, Y. Effects of alloying elements on elastic properties of Al by first-principles calculations. J. Min. Met. Sect. B Met. 2014, 50, 37-44. [CrossRef]

48. Amirkhanlou, S.; Ji, S. A review on high stiffness aluminum-based composites and bimetallics. Crit. Rev. Solid State Mater. Sci. 2020, 45, 1-21. [CrossRef]

49. Ceschini, L.; Dahle, A.; Gupta, M.; Jarfors, A.E.W.; Jayalakshmi, S.; Morri, A.; Rotundo, F.; Toschi, S.; Singh, R.A. Metal matrix nanocomposites: An overview. In Aluminum and Magnesium Metal Matrix Nanocomposites; Springer: Singapore, 2017; pp. 1-17, ISBN 9789811026805.

50. Alfonso, I.; Figueroa, I.A.; Rodriguez-Iglesias, V.; Patino-Carachure, C.; Medina, A.; Bejar, L.; Pérez, L. Estimation of elastic moduli of particulate-reinforced composites using finite element and modified Halpin-Tsai models. J. Braz. Soc. Mech. Sci. Eng. 2016, 38, 1317-1324. [CrossRef]

51. Tam, D.; Ruan, S.; Gao, P.; Yu, T. High-performance ballistic protection using polymer nanocomposites. Adv. Mil. Text. Pers. Equip. 2012, 10, 213-237. [CrossRef] 